Márton Baranyi ${ }^{1}$ :

\title{
German institutional hegemony in EU sustainability policies
}

German hegemony is a research topic subject to significant academic attention, especially within the studies linked to European integration. The existence of German hegemony within the EU is disputed, but several studies and models demonstrate that German hegemony within the European Union is significant but at the same time not desired (therefore the designation of Germany as a reluctant or benevolent hegemon). Is this true for the EU policies linked to sustainability as well, i.e. can institutional German hegemony be identified in the related policy fields? The study aims at assessing German institutional power linked to sustainability in the European Union (narrowing down policies linked to sustainability to EU energy and climate policy). It concludes that, based on a novel power ranking model assessing Member States' influence in the various EU institutions, German institutional power is not significant in the fields of EU energy and climate policy.

\section{Introduction}

EU sustainability policy is a broad and overarching topic that cannot be limited to certain policy fields. Since climate change and the related matters are complex and trigger multifaceted global problems, so is the fight against climate change and the push for sustainability a complex topic that encompasses many different policy fields, such as research and innovation, agriculture and rural development, transport and industry, energy, climate policy, and environmental policy. There is literally hardly any policy field that would not have a sustainability aspect. Sustainability is a thus complex topic and can only be assessed using a multifaceted approach. For the sake of feasibility, the current study narrows down EU policies linked to sustainability to EU energy and climate policy.

The current study aims at assessing German institutional hegemony in the field of EU sustainability policy over the last decade by creating a novel institutional power-ranking model that assesses the EU Member States' indirect influence in the field of EU sustainability policies, with special attention to the most powerful Member State, Germany. Germany is perceived as the EU's (reluctant) hegemon due to its considerable economic power and influence, yet the related research also unveils that, due to its history, Germany is not ambitioning power and is reluctant to take on a leadership role. Despite the lack of leadership appetite, Germany is forced to take on the leadership role by external events, such as the European Sovereign Debt Crisis (aka. crisis of the Eurozone). German hegemony within the EU is, therefore, a much debated and researched topic, and German hegemony is believed to be largely present in certain EU policies (e.g. EU economic policies in general and EU monetary policies in particular). However, does German hegemony also exist in other EU policy fields, e.g. in the area of EU policies linked to sustainability? Can German hegemony be quantified with regards this specific policy field in the relevant EU institutions?

In order to give an answer to the research question, the study starts by giving a brief literature review linked to the question of German hegemony within the EU. It then shortly covers the EU's and Germany's sustainability policies in order to (thirdly) introduce a novel EU institutional power model that allows

\footnotetext{
${ }^{1}$ Corvinus University of Budapest, PhD candidate

DOI: $10.14267 /$ RETP2021.02.13
} 
measuring German institutional power in the field of EU sustainability policies. Lastly, we draw attention to the limitations of the model but also deduct certain conclusions from the model.

Before going into specifics, it has to be emphasised that numerous simplifications are inevitable in order to assess Germany's potential institutional hegemony in the field of the EU's sustainability policies. First, we limit EU sustainability policies to EU climate and energy policy. Second, we limit the research of institutional hegemony to only two EU institutions and an EU executive agency: the European Commission, the European Parliament and the European Environment Agency. Thirdly, we limit our research to the already mentioned two policy fields in these two institutions as well, and assume that nationality can be seen as an influence advantage for the given Member State, whose national is holding a certain high-level position.

\section{German hegemony within the $\mathbf{E U}^{2}$}

The primary questions related to the alleged German hegemony within the European Union are the following: can Germany be considered as a hegemon, whether the hegemon stability theory be applied to the case of Germany, and if so, then can Germany be characterised as a fully-fledged hegemon within the European Union?

According to the conditions set by Keohane (control over raw materials, control over markets, control and control over capital, competitive advantage for high value-added products, and military superiority, [Keohane, 1984]), Germany does qualify as a hegemon. Despite being the EU's economic stronghold, performing well with regards market and capital control and having a competitive advantage in high valueadded products, Germany's influence in military power is negligible, and it needs to import its raw materials. Despite these deficiencies, some claim that Germany is clearly Europe's hegemon in economic terms, and could be defined as an embedded hegemon, given that it has played a leading role in the institution building and also has undertaken a disproportionate burden in institutionalizing regional cooperation [Crawford, 2015]. Others believe that Germany has been a benevolent hegemon since the creation of the single currency, in order to reduce fears of certain European partners from the returning power of reunited Germany [Proissl, 2010]. Others believe that Germany is a co-operative hegemon: the combination of supranational cooperation and hegemony results in a the significantly more stable international system, and Germany as the centre of a model based on cooperation grants the basis of a successful regional integration [Pedersen, 2002].

According to a different approach, Germany became a hegemon only lately and due to its heavy and enforced involvement in the crisis management of the Eurozone. The proponents of this approach argue that Germany exercises its power embedded in the EU institutions, shifting from a "cooperating hegemon" into a "reluctant hegemon" [Bulmer-Paterson, 2018]. Others emphasize the unwillingness and inevitability of German hegemony [Schönberger, 2012], while according to a similar view, Germany had to rise above its own interests and accept its inevitable fate by taking on the role of hegemon due to the Eurozone crisis [Kornelius, 2010]. Others believe that the German question is re-emerging not primarily as a security issue but as a geo-economic one: the German power is once again creating tensions and instability in Europe, due to Germany seeking to shape the European Union by imposing its own preferences on its partners but not taking on the financial responsibilities [Kundnani, 2014]. According to Kundnani, the paradox of German power is that, although the country has been striving for economic stabilization, it destabilizes the monetary union by spreading its own narrowly defined culture of stability. Similarly, others believe that

${ }^{2}$ For a more comprehensive literature review on Germany’s hegemony, see BARANYI [2021]. 
Germany, as a benign hegemon, has shifted in nature due to the Eurozone crisis, and that the country is acting unilaterally [Morisse-Schilbach, 2011]. Lastly, there are scholars who believe that Germany should bear all the responsibilities and obligations associated with hegemony, accepting that, against its will, Germany has become the central power of Europe. Münkler's the view is that Germany should abandon its hitherto reluctant role, maintain both the political and economic balance, and counteract the centrifugal forces of the periphery [Münkler, 2015].

\section{EU and German sustainability policy in a nutshell}

EU sustainability policies have existed for a long time. Due to the comprehensive nature and the importance of the topic, sustainability explicitly also enshrines in EU Treaties (first incorporated in the Treaty of Amsterdam, entering to force in 1999) as an encompassing objective of EU policies ${ }^{3}$. According to the current Treaty, sustainability is based on "balanced economic growth and price stability, a highly competitive the social market economy, aiming at full employment and social progress, and a high level of protection and improvement of the quality of the environment" [ARTICLE 3, TREATY ON EUROPEAN UNION, 2012].

Apart from the EU Treaty, sustainability also enshrines in various EU legislation and thus policies, such as, among others, the EU Sustainable Development Strategy (2001), the European Action for Sustainability (2016), or accompanying documents, such as the Towards a Sustainable Europe by 2030 Commission reflection paper (2019). EU sustainability policies operate in the context of the UN's 2030 Agenda, setting 17 Sustainable Development Goals. This means that the EU's sustainability strategy largely rests upon the implementation of the 2030 Agenda, meaning that sustainability has become a guiding principle for all Commission policies. Moreover, it also implies that the Sustainable Development Goals, including sustainability, are implemented in EU policies. This policy approach also enshrines in the Political Guidelines of the Von der Leyen Commission (2019).

Overall, Germany can be considered as a protagonist of EU sustainability policies and is usually strongly vocal with regards supporting various policy action in relation to climate change. This attitude can obviously traced back to domestic politics: notwithstanding the evolution of German public preferences over time, the German government was particularly receptive with regards to sustainability issues and ready to take political action to protect the environment and climate during the last decade.

The Energiewende (energy transition) is a well-known and deliberate German decision to phase out nuclear energy and increase the share of renewable energy sources in the German energy mix, following the severe earthquake and tsunami in March 2011 that triggered a nuclear incident in the Fukushima nuclear power plant. In addition, Germany has set a target of reducing its emissions by 40 percent by 2020 compared to 1990, and the related federal law (coming into force in 2019) provides for a 55 percent reduction by 2030. What's more, it was already stated in the 2013 coalition agreement that greenhouse gas emissions in Germany should be reduced by 80 to 95 percent by 2050 [CDU, 2013]. This objective was subsequently further tightened and concretised in the German Climate Action Plan to 2050, issued in November 2016, prepared its long-term national climate strategy (Klimaschutzprogramm 2050) in accordance with the provisions of the Paris Convention [BUNDESMINISTERIUM FÜR UMWELT, 2016]. Although the plan

\footnotetext{
${ }^{3}$ Evidently, sustainability as such is not only a policy issue that should be addressed at macro level, but due to the comprehensive nature of the concept, it must be addressed on all possible political and economic levels. Various studies also pinpoint the important role non-macro actors (SMEs) play in the field sustainability. See NAGY $(2011,2013)$
} 
was not legally binding and the strategy does not list specific measures to achieve the identified objectives, the main objective of the strategy is to achieve greenhouse neutrality by 2050. Climate neutrality in 2050 is also reflected in the German Sustainability Strategy 2018, in which emissions neutrality is no longer seen as a goal to be achieved not only on a federal level, but is also as an obligation on the level of the German federal states [BUNDESREGIERUNG, 2018].

Taking the assumed hegemony of Germany and the country's stark commitment with regards sustainability into account, we could easily assume that Germany plays a vital role in terms of the EU's sustainability policies and that German nationals occupy a number of high-ranking EU positions in the relevant domain.

\section{The institutional power-ranking model ${ }^{4}$}

As already briefly described above, the analysis of German hegemony focuses primarily on the country's role in the economic dimension of European politics in general, and Germany's role in the crisis of the Eurozone in particular. In order to assess the possible German dominance in the field of EU sustainability policies (limited to EU energy and environmental policy), there is a need for a complex model that calculates and displays institutional power, which seeks to assess the role of German officials in the top management of the relevant EU institution within the institutional framework. In order to do this, we develop a new complex model, which analyses the top management of selected EU institutions. The socalled institutional power-ranking model aims to establish a ranking based on the nationality of highranking Member States officials, based on the aggregation of scores allocated to the senior positions in order to demonstrate the weight of each Member State and rank the EU Member States. In other words, the model additively aggregates the points for all the high-ranking positions of all the institutions included in the model, resulting in a historically comprehensible and comparable aggregate score for each nationality of the officials of the selected EU institutions in the field of EU sustainability policy.

The period examined by the institutional power-ranking model is 2011-2020.

The model examines the following high-level positions in the following institutions/agencies:

1. Commissioner responsible for climate change (European Commission);

2. Commissioner responsible for the environment (European Commission);

3. Commissioner responsible for energy (European Commission);

4. Heads of cabinets of the above listed Commissioners (European Commission);

5. Director-General responsible for climate change (European Commission);

6. Director General responsible for the environment (European Commission);

7. Director General responsible for energy (European Commission);

8. Committee Chair for Environment (European Parliament);

9. Committee Chair for Industry, Research and Energy (European Parliament);

10. Director, European Environmental Agency

There is possibly no need to stress why the high-ranking positions within the European Commission dominates the list of examined positions: it can be argued that this institution is the most significant actor within the EU institutional framework when it comes to EU sustainability policies. The European Commission has various functions; among them is an agenda-setting and proposing legislation remarkably

\footnotetext{
${ }^{4}$ For the full institutional power-ranking model not limited to EU sustainability policies and the related EU institutions, see BARANYI [2021].
} 
important when it comes to EU sustainability policies. The relevant Commissioners play an important role with regards the above-mentioned functions, but so do their heads of cabinets, who are the Commissioners' gatekeepers and therefore informal power centres within the Commission. The importance of relevant Director-Generals is also straightforward: they are the managers leading the various directorates and who are responsible for the technical work done by the specialised entities. The relevant committee chairs in the European Parliament are also significant sources of power: important and relevant legislative work is being executed in the European Parliament that acts as the EU's co-legislator since the Lisbon Treaty took effect, and leading a specialised standing committee in the fields linked to sustainability policies wield significant influence on the committee chairs. Lastly, the director of the European Commission's specialised agency also has a role to play in the field of EU sustainability policies and their implementation.

Overall, with regards to the quantification of the high-ranking positions, the institutional-power model assigns a score from one to five for each of the above positions (Commissioner, Head of Commissioner's cabinet, Director-General, EP Committee Chair, Agency Director), depending on the importance of the high-ranking position. The allocation of points is summarised in the following table.

Figure 1: Allocation of points

\begin{tabular}{|l|c|}
\hline Position & Score \\
\hline Commissioner, European Commission & 5 \\
\hline Head of cabinet, European Commission & 3 \\
\hline Director-General, European Commission & 4 \\
\hline Committee Chair, European Parliament & 4 \\
\hline Director, European Environmental Agency & 2 \\
\hline
\end{tabular}

It is important to emphasise that the above scores allocated to each high-level position does not necessarily provide an accurate basis for comparison. In addition, it should be noted that the primary goal of establishing a power-ranking model is not to provide an accurate basis for comparison of the various highlevel positions, but to make the results aggregated from the allocated scores realistic.

Apart from the arbitrary score allocation, the model has one important assumption. The power-ranking model categorizes the various high-level officials of the various EU institution according to their national affiliation. The result of the aggregation is then understood as the magnitude of the power of the given Member State. However, it is important to emphasize that while high-ranking EU officials (by virtue of their nationality) provide both informal influence and power to their respective Member States, these officials represent the interests of the EU in the first place. That is, it should be made clear that although the institutional power-ranking model interprets the nationality of EU senior officials as a manifestation of Member State power, it does not assume that these officials do not carry out their duties impartially and in the interests of the EU.

Following a brief explanation of the model, Figure 2 gives an overview of the institutional powerranking model for the years 2011-2020. Altogether, one hundred high-level EU positions have been assessed from a nationality point of view to aggregate the Member States' influence in the field of EU sustainable policies. 
Figure 2: Institutional power-ranking model, 2011-2020

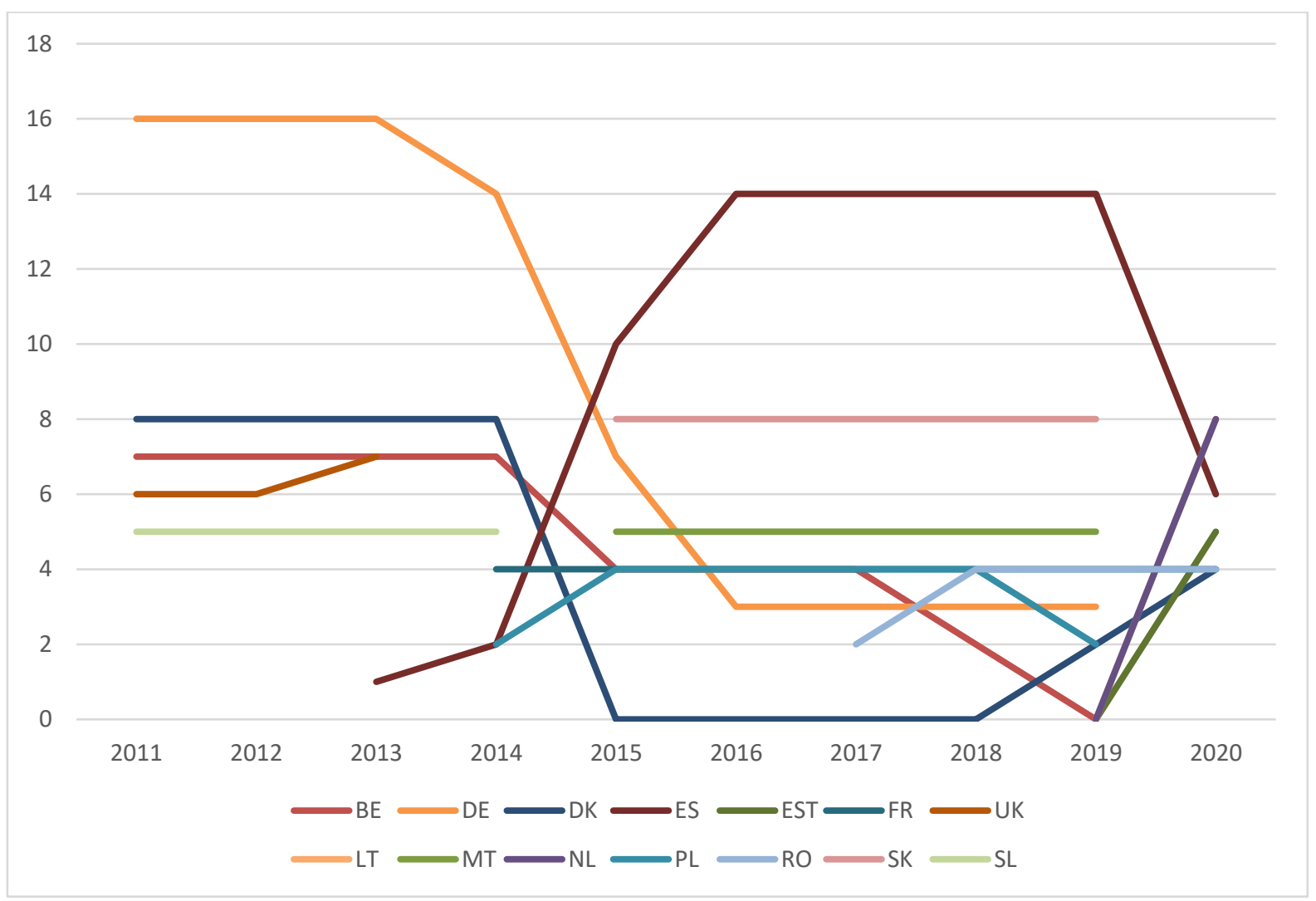

Source: Edited by Márton Baranyi based on data of EU institutions' statements

Despite the assumptions and limitations of the institutional power-ranking model, there are certain conclusions that can be drawn:

First, it is apparent that Germany does not play a dominant, let alone hegemonic role in terms of EU sustainability policy. A number of high-ranking German officials were detected in the relevant leading positions of EU institutions in the assessed period, but their proportion constantly diminished, and by the end of the decade, the proportion of leading German officials was by far not dominant compared to other Member State officials. It can be therefore concluded that, contrary to other EU policy fields where German hegemony is apparent and constant, German high-level officials do not monopolise the key positions in terms of EU policies linked to sustainability.

Secondly, the power-ranking model reveals that power in the field of EU policies linked to sustainability is dispersed among the different Member States. Germany can be considered as a dominant power in the first part of the decade, but then its power diminished and Spain took over domination for some years. Nevertheless, there are several other Member States' high-ranking officials also present throughout the whole period, in total, 14 Member States' nationals are represented in the power-ranking model during the examined period, thus it can be argued that overall, EU sustainability policy is characterised by dispersed leadership.

Thirdly, also due to the selected number of institutions subject to the analysis of the model, the Commission seems to be overrepresented: three Commissioners and subsequently three heads of the cabinet are subject to change in 2014 and 2019, and the end of the mandate of Commissioners does have an apparent impact on the institutional power-ranking model. High-level positions filled by smaller Member States (e.g. Malta, Slovenia) gives the countries a relatively large share within the power matrix, nevertheless, this absolutely diminishes once the end of the mandate of Commissioners occurs. 


\section{Limitations of the model}

It is clear that the model builds on certain limitations. Most importantly, only two EU policies are taken into account, despite sustainability being a complex topic that could be fully assessed only by using a multifaceted and comprehensive approach. Secondly, only two EU institutions (and one agency) are part of the institutional power-ranking model, and only a number of high-level positions are subject to the calculations of the model, while in reality EU policies linked to sustainability cannot be narrowed down to certain high level positions in only two EU institutions and one executive agency. Thirdly, the model translates the nationality of high ranking EU officials directly into Member State influence, which in reality is way more complex: EU officials represent EU interests (and not those of their Member States), even if it is an unspoken truth that the Member States do benefit from their citizens holding high level positions in the EU institutions. Lastly, the model assigns weights to each position, despite this being clearly arbitrary: there are no factual foundations with regards to the exact importance and weight of the positions in question, and therefore how these high-level positions can be quantified.

\section{Conclusions}

Despite the institutional power-ranking model's apparent weaknesses and simplifications, the model demonstrates that EU institutional leadership with regards EU sustainability policies are dispersed: several Member State nationals are occupying high-level positions throughout the analysed period and no Member State has a significant power throughout the period that could be labelled as dominant or hegemonic power. Consequently, both were the subject of the current analysis in a dominant position regarding EU sustainability policies, and contrary to other policy fields in the EU, German institutional power is not significant in the fields of EU energy and climate policy.

\section{References:}

Baranyi, M. (2021): Hegemón-e Németország? Doktori disszertáció, Budapesti Corvinus Egyetem

Bulmer S.-Paterson, W. (2018): Germany and the European Union: Europe's Reluctant Hegemon? Red Globe Press, London

BUNDESMINISTERIUM FÜR UMWELT (2016): Klimaschutzprogramm 2050

BUNDESREGIERUNG (2018): Deutsche Nachhaltigkeitsstrategie

CHRISTLICH DEMOKRATISCHE UNION DEUTSCHLANDS (CDU) (2013): Koalitionsvertrag zwischen CDU, CSU und SPD

Crawford, B. (2015): German power and embedded hegemony in Europe, in: Colvin, Sarah: The Routledge handbook of German politics and culture, London, New York, pp. 329-348.

EUROPEAN COMMISSION (2001): A Sustainable Europe for a Better World: A European Union Strategy for Sustainable Development

EUROPEAN COMMISSION (2016): Next steps for a sustainable European future; European action for sustainability

EUROPEAN COMMISSION (2019): Towards a Sustainable Europe by 2030 - Reflection paper

EUROPEAN COMMISSION (2019): Political Guidelines of the Next European Commission 2019-2024

GESETZ ZUR EINFÜHRUNG EINES BUNDES-KLIMASCHUTZGESETZES (2019)

Keohane, R. (1984): After Hegemony - Cooperation and Discord in the World Political Economy, Princeton University Press, Princeton

Kornelius, S. (2010): Hegemon wider Willen, Süddeutsche Zeitung 
Kundnani, H. (2014): The Paradox of German Power, Hurst \& Company, London

Morisse-Schilbach, M. (2011): "Ach Deutschland!": Greece, the Euro crisis, and the costs and benefits of being a benign hegemon, Internationale Politik und Gesellschaft, No. 1.

Münkler, H. (2015): Macht in der Mitte - Die neuen Aufgaben Deutschlands in Europa, Körber Stiftung, Hamburg

Nagy S. Gy. (2013): The internationalization of the Spanish SME sector, Society and Economy 35: 1 pp. 71-86., 16 p.

Nagy S. Gy.-Palánkai T.-Miklós G.-Endrődi-Kovács V.-Baranyi M. (2011): Internationalisation

(Transnationalisation) of the Enterprise Sector, Budapesti Corvinus Egyetem, 66 p.

Pedersen, T. (2002): Cooperative Hegemony: Power, Ideas and Institutions in Regional Integration, Review of International Studies, Vol. 28, No. 4, pp. 677-696.

Proissl, W. (2010): Why Germany fell out of love with Europe, Bruegel Essay and Lecture Series, Brussels

Schönberger, C. (2012): Hegemon wider Willen - Zur Stellung Deutschlands in der Europäischen Union, Merkur, Januar 2012, Vol. 66, Heft 752, pp. 1-8.

TREATY ON EUROPEAN UNION (2012) 